\title{
Research Challenges and Advancements in the field of Sustainable Energy Technologies in the Built Environment
}

\author{
Paris A. Fokaides* $*$, Rasa Apanaviciene, Jurgita Černeckiene ${ }^{\circledR}$, Andrius Jurelionis, \\ Egle Klumbyte, Vilma Kriauciunaite-Neklejonoviene, Darius Pupeikis, Donatas Rekus, \\ Jolanta Sadauskiene, Lina Seduikyte ${ }^{\circledR}$, Laura Stasiuliene, Juozas Vaiciunas, Rokas Valancius \\ and Tadas Ždankus \\ Faculty of Civil Engineering and Architecture, Kaunas University of Technology, Studentu str. 48, \\ LT-51367 Kaunas, Lithuania; rasa.apanaviciene@ktu.lt (R.A.); jurgita.cerneckiene@ktu.lt (J.Č.); \\ andrius.jurelionis@ktu.lt (A.J.); egle.klumbyte@ktu.lt (E.K.); vilma.kriauciunaite@ktu.lt (V.K.-N.); \\ darius.pupeikis@ktu.lt (D.P.); donatas.rekus@ktu.lt (D.R.); jolanta.sadauskiene@ktu.lt (J.S.); \\ lina.seduikyte@ktu.lt (L.S.); laura.stasiuliene@ktu.lt (L.S.); juozas.vaiciunas@ktu.lt (J.V.); \\ rokas.valancius@ktu.lt (R.V.); tadas.zdankus@ktu.lt (T.Ž.) \\ * Correspondence: paris.fokaides@ktu.lt
}

Received: 8 September 2020; Accepted: 7 October 2020; Published: 13 October 2020

\begin{abstract}
Inevitably, the 21st century has initiated a series of developments in the construction industry, leading to its digitalization and resulting in a series of innovative approaches and practices. At the same time, the construction industry, being one of the main global environment polluters, should fulfil well-established, as well as novel, sustainability requirements in order to evolve in harmony with the rising concerns on the availability of natural resources. This overview study aims to present the main developments, research, and scientific challenges in the field of sustainable construction, emphasizing the field of energy. The study aims to present a state-of-the-art scientific discussion on the sustainable built environment topic by analyzing cutting edge topics in the fields of building elements and whole building energy assessment, of indoor air quality and low carbon buildings, as well as on sustainable energy systems and smart buildings. The study also presents the state-of-the-art in existing tools which are adopted for the assessment of the sustainable built environment, including the use of digital tools and building information modelling for the energy assessment of the built environment, as well as the application of Life Cycle Assessment on building-related processes. Cross cutting issues related to the analysis of the building sector in the Industry 4.0 era, such as sustainability management topics and environmental geomatics are also discussed. The study concludes in those fields which will be of interest of the scientific community in the following years, towards achieving the goals of the sustainable development of the building sector.
\end{abstract}

Keywords: sustainable energy; life cycle assessment; building information modelling; indoor air quality; energy systems; whole building energy analysis

\section{Introduction}

According to the United Nations Development Programme (UNDP) [1], between the years of 2000 and 2016, the number of people worldwide without access to electricity decreased to below one billion and was reduced from $22 \%$ to $13 \%$. The UN has predicted that the global population growth rate will decline from $+1.0 \%$ in 2020 to $+0.5 \%$ in 2050 and will exceed 10 billion in 2100 . Yet as the global population grows, so will the necessity for affordable energy. Capitalizing on renewable energy technologies and in energy saving, promoting best practices for increasing Negawatts, and ensuring 
energy for all constitutes a set of major goals, not only for the Energy Union of the EU, but as well for the sustainability development goals (SDG) of UNDP. Increasing infrastructure and improving technology to allow affordable, green, and efficient energy worldwide will enable the growth and support the environment.

The Energy Union and the Energy and Climate Policy Framework for 2030 established ambitious commitments to reduce greenhouse gas emissions by at least $40 \%$ by 2030 and set an energy savings target of $32.5 \%$ by 2030 . The building sector is one of the largest energy consumers in the European Union (EU), responsible for approximately $40 \%$ of the final energy demand and $36 \%$ of Carbon Dioxide (CO2) emissions, and subsequently has a significant role in the European Commission's proposal for its energy saving goal. An estimated $97 \%$ of the EU's building stock (corresponding to close to 30 billion $\mathrm{m}^{2}$ ) is considered energy inefficient, while up to $75-85 \%$ of it will continue to be utilized in 2050. The EU has proposed a set of directives to phase out inefficient buildings. The Energy Performance of Buildings Directive (EPBD), introduced in 2002 and revised in 2010 and in 2018, is the legislative and policy instrument tool to improve the energy performance of buildings across Europe, focusing on both existing and new buildings. The anticipated energy savings from the potentially appropriate application of the Directive's articles are evaluated to be 60 Mtoe by 2020, while it requires the transformation of existing buildings into Nearly Zero Energy Buildings by 2050. Energy Performance Certificates (EPCs), introduced in 2002 as a mandatory requirement in Member States (MSs) when constructing, selling or renting a building, are an essential part of EPBD; EPCs play an important role in this process as they serve as a transparent information instrument for building owners and real estate stakeholders are among the most important information sources regarding energy performance in the EU's building stock.

The scope of this study is to analyze the current research trends in the field of sustainable built environment, with emphasis on energy-related applications (Figure 1). The analysis is performed through an overview of the conducted work at the Sustainable Energy for the Built Environment Research Group (SEBERG) at the Kaunas University of Technology (Lithuania) within the time period 2015-2020. Over 90 studies were reviewed and analyzed, composing a study which aspires to reveal the research trends in the field in the upcoming years. The study focuses in the fields of indoor air quality, sustainable energy systems, whole building energy assessment, sustainability management, and environmental geomatics, as well as on building information modelling and life cycle assessment, tools which are valuable in achieving the goals for a sustainable built environment.

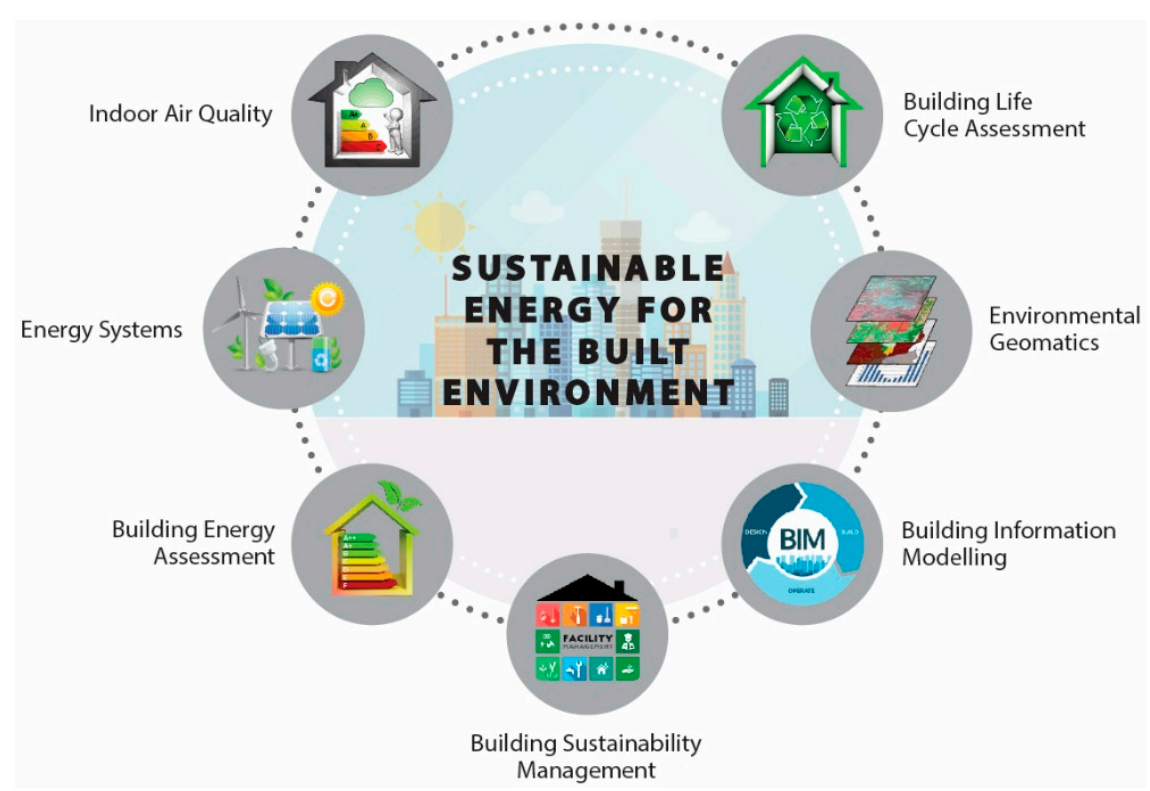

Figure 1. Research Trends in the field of Sustainable Energy for the Built Environment. 


\section{Major Research Advancements in the Scientific Fields of Sustainable Energy in the Built Environment}

\subsection{Indoor Air Quality}

Indoor air quality (IAQ) matters greatly since most of people's time is spent indoors; modern societies live, work, learn, entertain themselves and even travel in enclosed environments. The IAQ depends on the presence of pollutants in the indoor air and more attention should be payed to it, as over the past decades the sector of buildings has changed significantly. Energy efficiency regulations resulted in more airtight buildings, therefore adequate ventilation has to be provided. Mechanical ventilation is a must in almost any building, otherwise pollutants will be accumulated and will have a negative impact on the building occupant's health, productivity, and comfort. However, installing a ventilation system does not always mean that high IAQ levels will be ensured; ventilation systems can be poorly controlled and maintained [2], or building materials, household products, and occupant activities that emit pollutants can raise problems during construction or exploitation of the building [3]; therefore, ventilation systems sometimes should not be the only strategy that is used. A previous study of Ciuzas et al. [4] showed that high IAQ in buildings could be achieved by wisely combining ventilation and additional filtration techniques of indoor air quality control; pollutant removal efficiency can increase by $20 \%$ by using these techniques.

In addition to existing building energy efficiency regulations, a number of "green" building certification programs have been developed, e.g., LEED (Leadership in Energy and Environmental Design) which is used in the United States and BREEAM (Building Research Establishment Environmental Assessment Method) used in the United Kingdom [5,6]. The impact of buildings on the environment throughout their life cycle is certified under these programs, evaluating such criteria as energy consumption for space heating and cooling, water consumption, indoor environment, pollution, waste management, ecology, etc. According to Wei et al. [7] only $7.5 \%$ of the total evaluation of the building is related to IAQ assessment. The main indoor air pollutants suggested to be evaluated in these certification programs are carbon dioxide (CO2), formaldehyde, and other volatile organic compounds (VOCs), with only $6.7 \%$ of certification programs suggesting ozone (O3) and SVOCs. Unfortunately, these certification programs are applied on a voluntary basis and are not mandatory for all buildings. The main pollutant suggested to be evaluated in national regulations is usually CO2 [8] while other pollutants, such as VOCs should also raise concern, as these pollutants are suggested to be called "modern exposure", meaning that there is a variety of such pollutants and it is related to new materials, products, and changed occupant activities [9]. Following the recommendations of selecting environmentally friendly materials in order to have sustainable building does not ensure high IAQ level either. Several previous studies show that "green" building materials also emit pollutants, but in much smaller quantities $[10,11]$.

In terms of IAQ in enclosed environments, many factors have to be taken into a count, e.g., distribution of gaseous pollutants can be affected by dynamic (generated by ventilation system) and convective (generated by heating systems, occupants or equipment) flows. Combined impacts of mixing ventilation and heating systems on dispersion of volatile organic compounds emitted at near-floor level was investigated by Stasiuliene and Jurelionis et al. [12-15]. Experiments and CFD simulations have shown that pollutant dispersion depends on the heating system type ([12-15]. If occupant is present, the convective boundary layer of the occupant entrains pollutants from lower parts of the room to the breathing zone; relative pollutant concentrations in the occupant breathing zone compared with warm air heating were lower with underfloor heating by $12 \%$, and $24 \%$ with radiator heating [16]. Combined impacts of heating and mixing ventilation in sport halls were investigated by Seduikyte et al. [17]. CFD simulations showed that with the same heating output for air heating, underfloor heating combined with mechanical mixing or displacement ventilation ensures higher temperatures in the occupied zone, creating a potential for energy savings. 
Furthermore, while discussing IAQ control strategies indirectly related to ventilation, it has to be mentioned that the quality of ventilation depends not only on the amount of air that is introduced to the space, but also on the position of air inlets and outlets devices, and air supply pattern or air supply velocity [18].

Increased airtightness of buildings has a chain effect on the amount of pollutants in the building and human health (Figure 2). Due to the wide variety of pollutants, pollutant monitoring technologies should play significant role in the very near future as the technologies of lower cost sensors evolve fast [19-21].

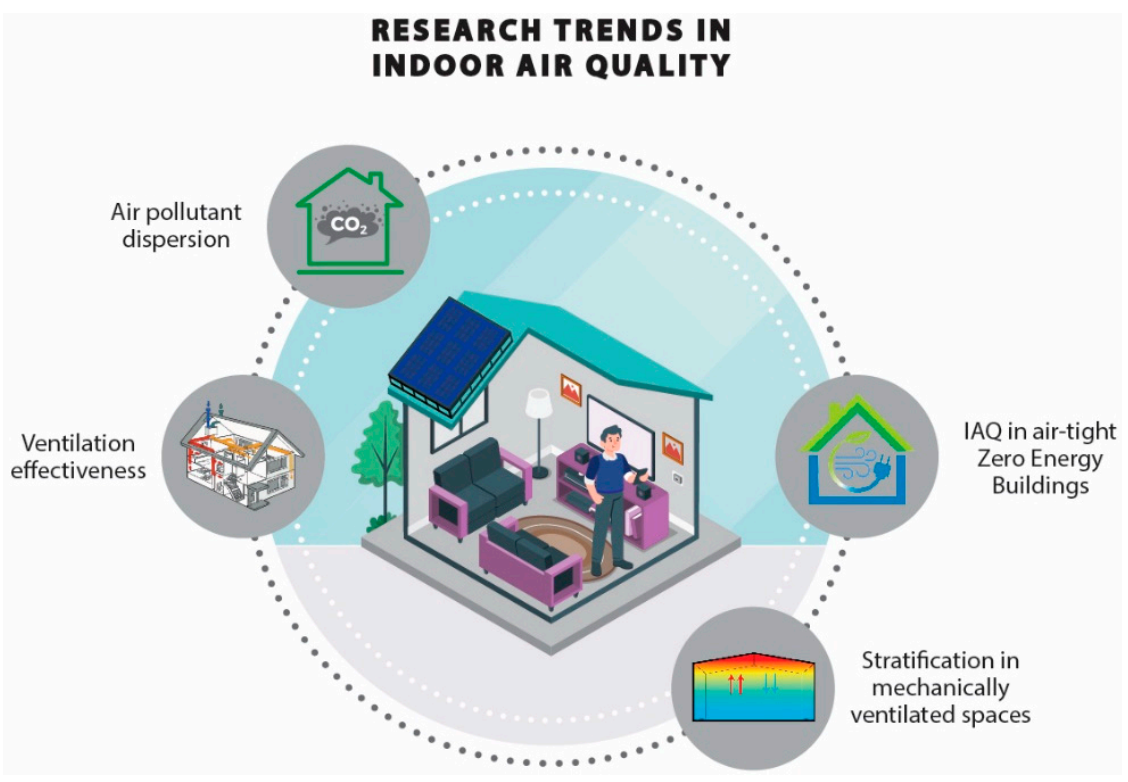

Figure 2. Research Trends in Indoor Air Quality Research.

\subsection{Sustainable Energy Systems for the Built Environment}

Several parameters have led in the recent years to the promotion and penetration of renewable energy technologies into the built environment. These can be summarized as follows:

- the fact that the fossil energy sources are limited

- the environmental issues resulting from the careless consumption of energy related to the greenhouse effect

- the energy security issues that arise with the use of non-indigenous energy resources

The energy scientific community is under pressure to improve the conditions under which the renewable energy resources are exploited in terms of their efficiency and their integration into the built environment. To this end, the scientific initiatives and the research reports related to the topic of the integration of renewable energy technologies into the built environment are numerous [22].

Concerning biofuels, the main technological application which is employed in the built environment is the biomass boilers, mainly exploiting solid biofuels (pellets). Environmental concerns concerning the pollutant emission of such boilers are limited with the use of competent European standards, which are included in the eco-design package of regulations. Topics regarding the class of biofuels burnt in biomass boilers are also governed over a series of European standards, which describe the elemental and proximal necessities of the applied fuels. Research concerning the management of ash also delivered reliable solutions for the exploration of this waste stream in an ecologically friendly method [23].

Solar thermal technologies represent one of the most mature and well-established methods of heat production for the built environment. As early as the 1970s, this technology was widely used in southern Europe to eliminate the energy needs for domestic hot water. In some parts of southern Europe, the 
use of a solar thermal collector can meet more than $50 \%$ of the annual needs of a building in domestic hot water, where this percentage is lower for northern European countries. Research initiatives in this area focus on the promotion of alternative materials and collectors, in addition to the flat collector, which will result in increased efficiency, as well as in the analysis of their energy performance [24]. Several studies were also implemented, with the aim to improve the design of solar thermal collectors through the adoption of more environmentally friendly practices $[25,26]$. The penetration of solar thermal technologies into northern European countries, where their contribution to the energy mixes is still limited, is also another topic of scientific interest [27,28].

The number of shallow geothermal energy installations has been increasing all over Europe over the last decades due to their increased energy efficiency as well as on the basis of policy initiatives aiming to the increase in the use of renewable energy technologies. In Nordic countries, geothermal heat pumps have achieved significant rates. This is also the case in other European countries with rather cold climates, such as the Netherlands, Germany, France and Austria, while Sweden is the front-runner of the EU market [29]. In 2016 it is estimated that over half a million of heat pumps were installed in Sweden. The lack of a regulatory framework for the operation of geothermal heat pumps at European level results in research initiatives, with the aim to draft and develop the required technical standardization [30].

As far as wind energy is concerned, there are obvious limitations for the integration of wind turbines to the built environment, mainly related to the limited efficiency of the technology, as well as the restrictions which are met for the wind potential in the built environment [31,32]. However, a promising application which has recently been investigated concerns the wind to thermal conversion technologies for heat production (Figure 3). Wind to thermal energy technologies, although they have been explored systematically since the 1950s, did not attracted much interest. Novel wind to thermal energy conversion systems, which could be installed and exploited in areas of high wind potential and increased needs for space heating have been recently investigated. The rationale of this application concerns the heat produced by a hydraulic system due to friction losses. The energy required to drive the hydraulic pump in this case is provided by a wind turbine [32-35].

\section{RESEARCH TRENDS}

IN ENERGY SYSTEMS

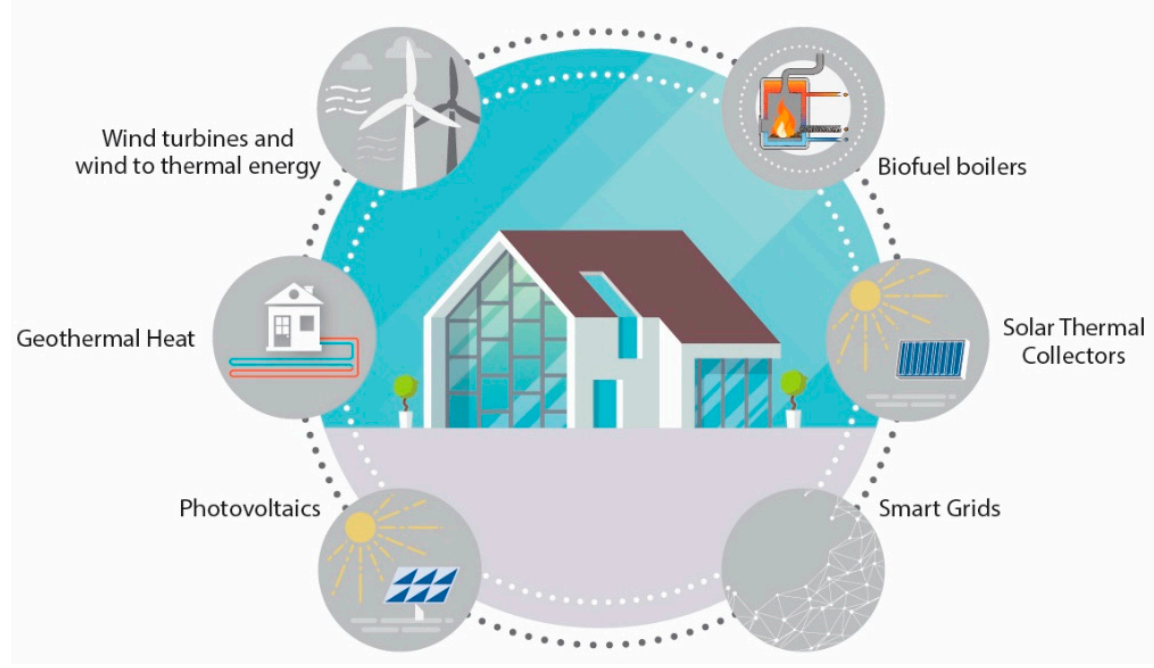

Figure 3. Research Trends in Sustainable Energy Systems.

\subsection{Building Energy Assessment}

The research on the energy efficiency of the building sector has been at the forefront of the research activities in the field of energy sciences, as buildings are one of the major energy consumers of all developed states. The European and national policies on the field of energy savings in the 
built environment were initiated back in the mid 1970s, starting from the era of the oil crisis [36]. The document, though, radically revised the conditions in Europe in the field of energy efficiency of buildings and led to a significant transition in the way the EU member states develop was the EPBD directive, namely the directive on the energy performance of buildings [37]. This directive, which was further enhanced with the successional recasts of 2010 [38] and 2018 [39], introduced among other elements:

- The minimum requirements of building elements with regard to their energy performance

- The certification of buildings with energy performance certificates, requiring the whole energy assessment of buildings

- The development and realization of the nearly zero energy building concept

- The necessity for the development of a joint methodology for the definition of the energy performance of buildings, based on regulations and standards

The research in the field of building physics and energy has been aligned since the early 2000s on these elements, with the aim to deliver the required knowledge to satisfy these requirements.

Concerning the analysis of the energy performance of building elements, scientific work has been implemented in the investigation of the thermal properties of novel thermal insulating materials, such as for example phase change materials [40]. The nature of research has been both experimental, as well as numerical [41,42], the latter being mainly based on finite element methods.

A relevant topic which has been of the highest interest of the building physics research community is the investigation of the performance of thermal bridges [43-45]. A thermal bridge is an area or a component of an object which has lower thermal resistivity than the surrounding materials, producing a pathway of a higher rate of heat transfer [46]. As the legislative requirements for enhanced insulation of building components are becoming firmer, the significance of avoiding thermal bridges in low energy buildings is also increasing [47].

The whole building energy assessment contains both research on the performance of the entire building shell with regard to divert climatic conditions, and the thermal comfort. Both disciplines are analyzed with the use of heat transfer modelling, as well as with the exploitation of principles related to fluid mechanics, mainly concerning the behavior of the indoor air. Studies in this field focus on issues such as the definition of the thermal stratification and of the ventilation performance in thermal zones which are ventilated with the use of mechanical systems [17]. Research has also been documented in different types of buildings, including offices, educational buildings, and even greenhouses [48] (Figure 4).

In the field of nearly zero energy buildings, the current trails in research emphasize the development of scenarios for achieving nearly zero energy buildings under conditions of either high heating and cooling loads, or in countries where the energy mix neither provides off side renewable energy supply, nor do the conditions allow the integration of on-site renewable energy technologies [49]. The integration of zero energy buildings into smart cities also constitutes a major research challenge which has been under investigation in recent years [50]. 


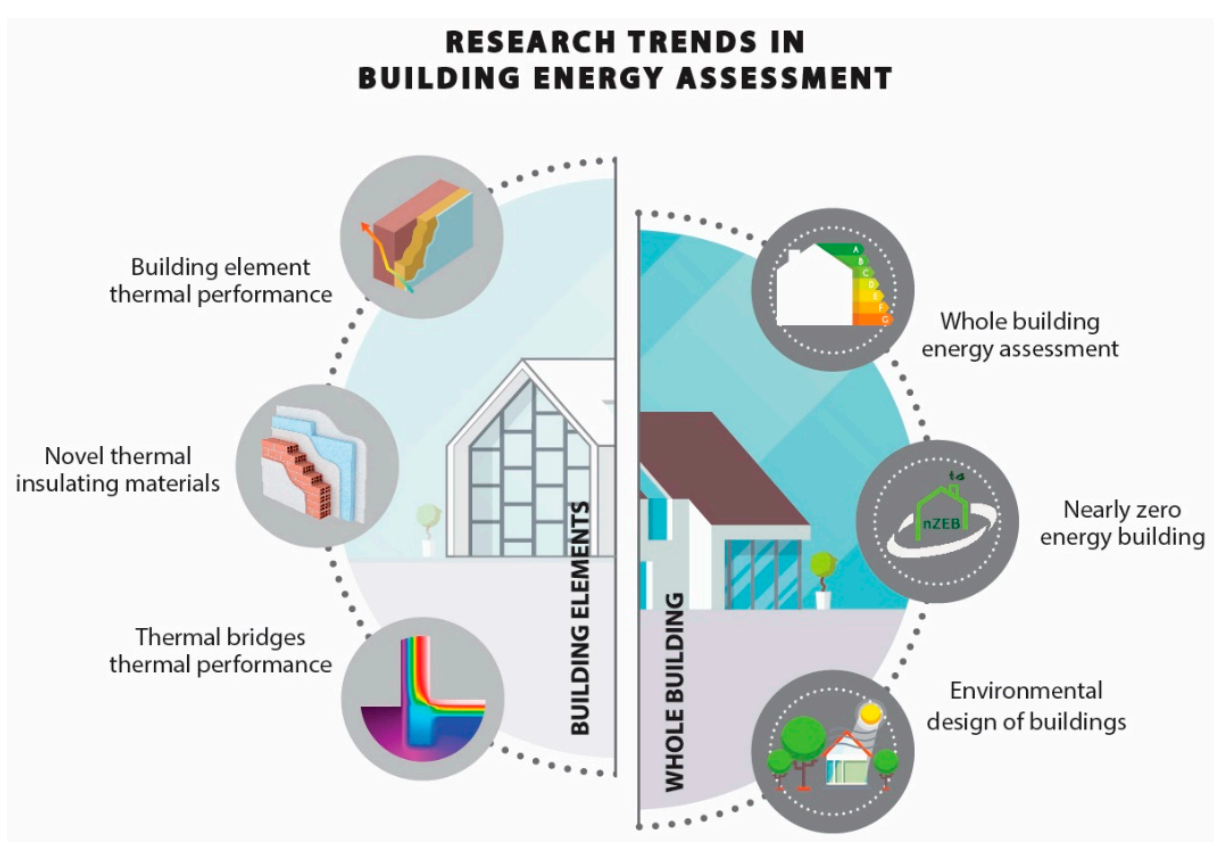

Figure 4. Research Trends in Building Energy Assessment.

Concerning the future challenges in the field of energy efficient buildings, these are anticipated to include the development and establishment of the Smart Readiness Indicator (SRI) of building equipment. Among the new elements introduced to the revision of the Directive is the introduction of an optional European scheme for rating the "smart readiness" of buildings for the promotion of smart building technologies. The smart readiness indicator (SRI) for buildings will be employed for measuring the capacity of buildings to use information and communication technologies (ICT) and electronic systems for adjusting the operation of buildings to the needs of the occupants and the grid and consequently also improve the energy efficiency and overall performance of buildings. The establishment of the SRI is expected to increase the energy use awareness of building owners and occupants and exploit the opportunities for energy and cost savings, acquired with the installation of devices and equipment for building automation and for the electronic monitoring of technical building systems. This will provide readily available data to the occupants about the actual energy consumption of the building, as well as the actual savings that are achieved with the new enhanced functionalities.

\subsection{Sustainability Management}

With the acceleration of the 4.0 industrial revolution, the construction industry is facing challenges to increase productivity and efficiency, as well as to improve the value of infrastructure and enhance quality following the principles of sustainability. Sustainability management is therefore a major field of scientific interest in the sustainable built environment (Figure 5). In view also of the necessity for the development and establishment of a smart built environment, as well as smart cities, a non-exhaustive list of topics included in the field of sustainability management of the built environment may include topics such as 


\section{RESEARCH TRENDS IN BUILDING} SUSTAINABILITY MANAGEMENT

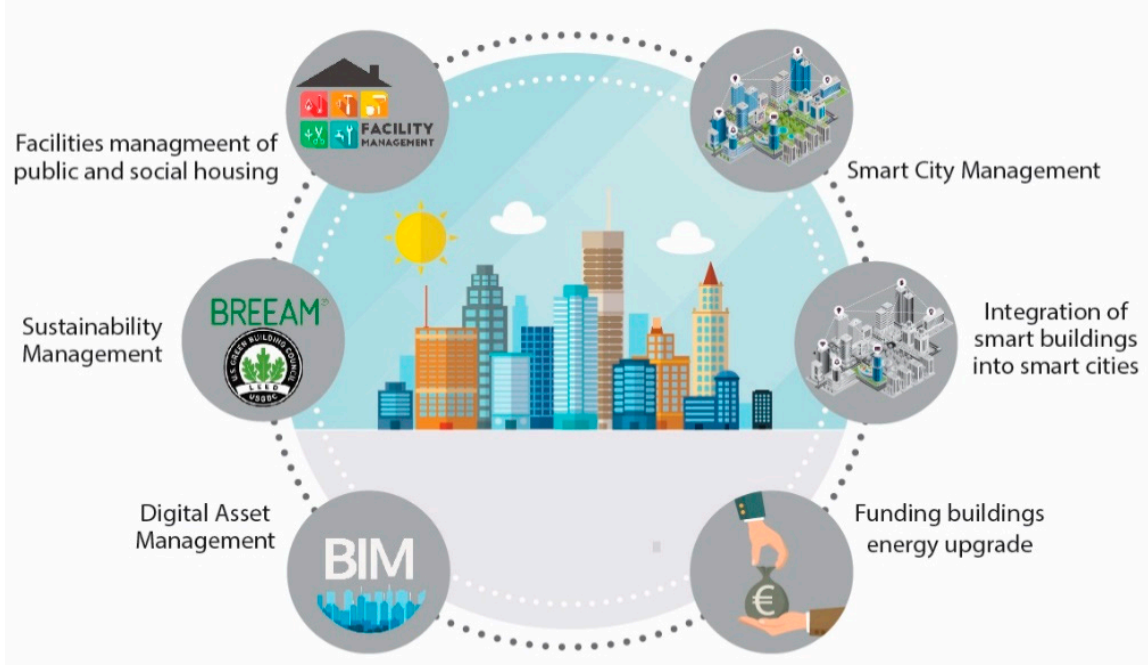

Figure 5. Research Trends in Sustainability Management.

- Construction management, using digital construction tools

- Sustainability management, aligned with best practices in the field of sustainable built environment (eg buildings sustainability schemes)

- Facilities management, by employing state of the art technologies such as digital twins and digital asset management

- Smart buildings and smart cities management, with emphasis on the integration of smart buildings into smart cities' infrastructures

- Resources and funding required for smart buildings and smart cities management

Taking the Republic of Lithuania as a case study of an EU member state, and according to data from 2019, the state had 28.1 thousand buildings with a total area of 10.5 million $\mathrm{m}^{2}$, and 77 thousand kilometers of roads and railways. The residual value of these assets is $€ 5$ billion, of which $€ 180$ million is allocated for the maintenance of buildings, and $€ 500$ million per year for road maintenance. Analyzing the costs of building maintenance in the life cycle of a building, it is seen that $3 \%$ of the assets concerns design costs, $17 \%$ is allocated for construction, and $78 \%$ of the invested assets is incurred during the operation of the building; $2 \%$ of the total amount is for the demolition phase [51]. These facts and numbers emphasize the significance of the sustainability management sector in the field of sustainable built environment.

Sustainability management in the EU is regulated by legal acts, directives, regulations and standards. The primary document which leads to sustainability management is ISO 37120:2018, a document which defines and establishes methodologies for a set of indicators to steer and measure the performance of city services and quality of life. This document follows the principles set out in ISO 37101 and can be used in conjunction with ISO 37101 and other strategic frameworks. ISO 37120:2018 is applicable to any city, municipality, or local government that undertakes to measure its performance in a comparable and verifiable manner, irrespective of size and location. The indicators included in this standard and the associated test methods were developed aiming to support cities to

- measure performance management of city services and quality of life over time,

- learn from one another by allowing comparison across a wide range of performance measures, and

- $\quad$ support policy development and priority setting [52].

In ISO TR 37121:2017, an inventory of existing guidelines and approaches on sustainable development and resilience in cities is provided [53]. 
Sustainability management is increasingly spread in the scientific field of construction engineering. The background of this approach is that construction engineering is not only construction design and construction processes, but also the planning and management of construction, maintenance, reconstruction, and real estate (RE) management [54]. During the decade 2009-2019, 38993 scientific papers on the topic of sustainability management were published in the Web of Science database (Figure 6). Web of Science search results show that sustainability management is continuously increasing, revealing the potential of sustainability management (Figures 6 and 7).

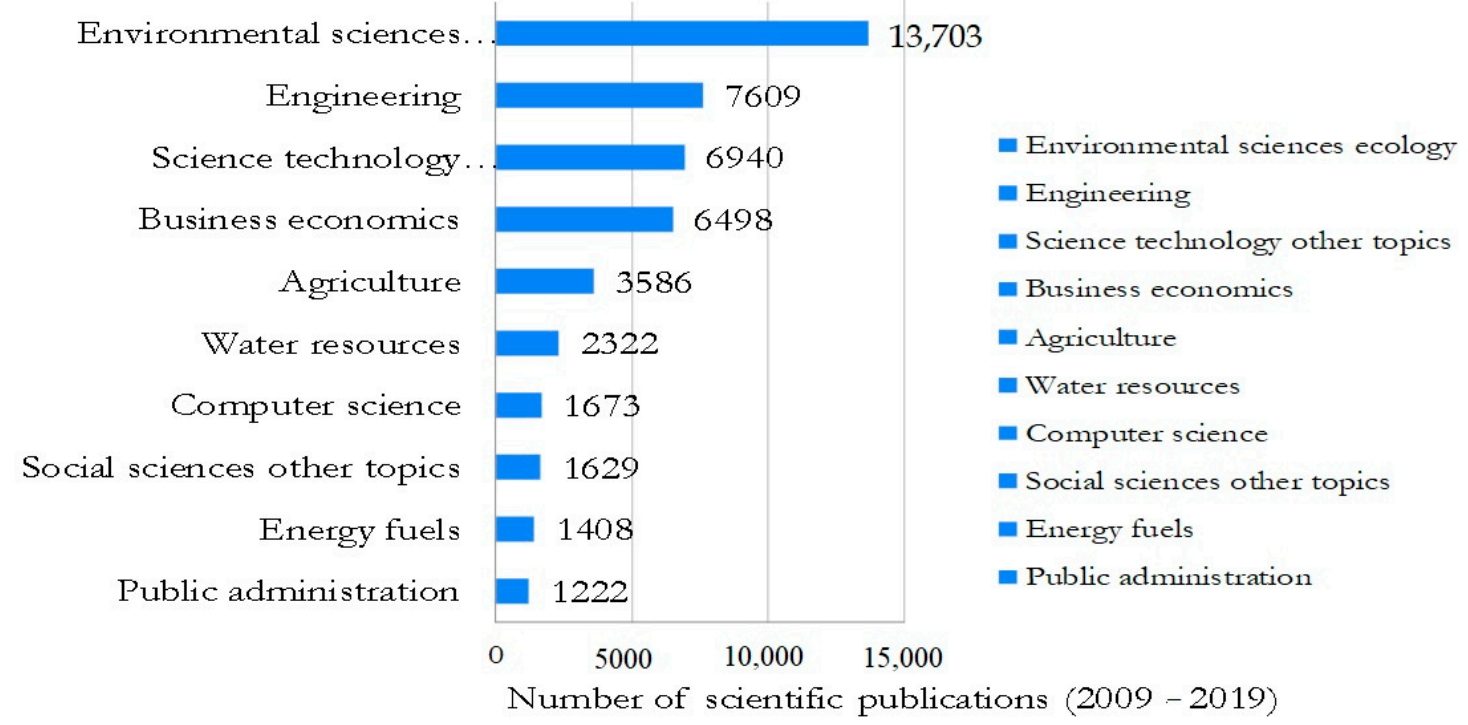

Figure 6. Top 10 research areas for the Sustainability management (2009-2019).

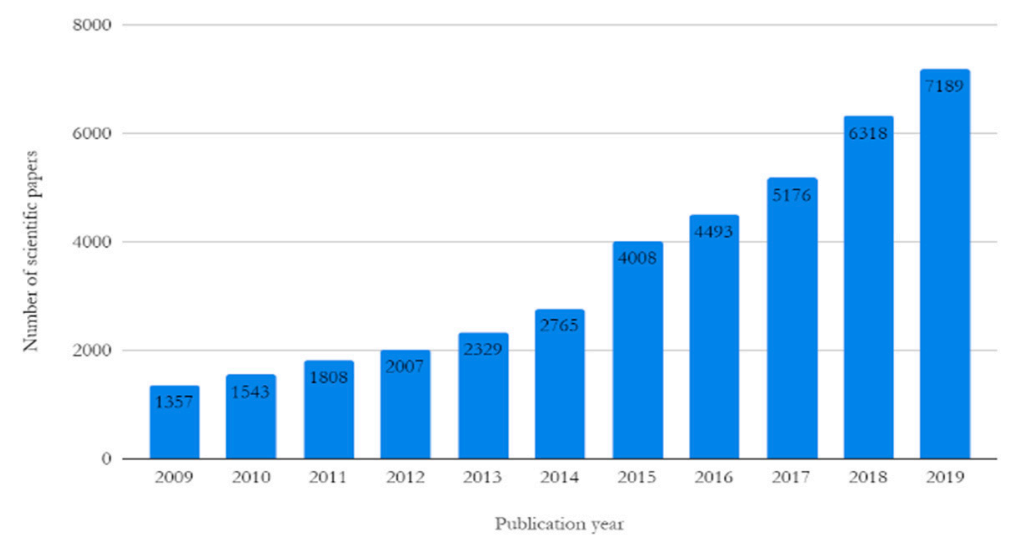

Figure 7. Number of scientific articles for the sustainability management topic (2009-2019).

Building sustainability assessment schemes (BSAS) are vital for evaluating, assessing, and implementing sustainability objectives throughout the life cycle of a building [55]. Typical examples of BSAS are LEED, BREEAM, DGNB and the recently launched EU scheme Levels [56]. Also, sustainability aspects and their peculiarities are essential to an aging society in the design and management of their living environment. They highlight the critical issues of sustainable aging and offer the possibility to complement existing design concepts with a biophilic design concept to strengthen their social, psychological, and environmental aspects $[57,58]$.

Tailored models and tools for the assessment of the sustainability of specifically social and public housing have also been recently developed. Klumbyte et al. [59] investigated the main steps through the development of a Suppliers Inputs Process Outputs and Customers (SIPOC) system for building management assessment, with a focus on social housing. The scheme was further developed 
for sustainable real estate management, including the documentation of building requirements, the assessment of buildings' compliance with established requirements, the assessment of buildings against their compliance with applicable requirements, and the assessment of decisions on alternatives for real estate (RE) management [60].

Another field of scientific interest is the integration of sustainable practices and sustainable buildings into smart cities. Smart cities are expected to prevail in the European built environment in the following years. The key points which are expected to regulate energy management in upcoming smart cities is also a topic of interest for the scientific literature and initiatives in the field of construction management [61]. The concept of smart buildings has been developed in parallel with the concept of smart cities. Therefore, tasks related to the required practices to integrate smart buildings into smart cities also present significant interest [62]. The investigation of financial management aspects of the built environment and supporting schemes towards transition to a sustainable environment also concerns the scientific community of Sustainability $[63,64]$.

\subsection{Building Information Modelling}

Building Information Modelling (BIM) is a procedure of the development of a smart model that links the Architecture, Engineering, and Construction industries, enabling effectiveness in design, construction and operation of buildings and infrastructure. The engineers draft digital-based models in BIM software that encompass data related to the buildings' physical and functional features. The competitive benefit of BIM technology compared to contemporary techniques is the teamwork of AEC experts on a joint model database allowing the efficient data exchange within the overall project life cycle. The model data describes valued information such as design essentials, as well as the performance and relation among model components. To this end, any variations in the model's elements enable a fast and precise update of the view of all linked sections.

BIM can be adopted at any stage of the construction of a building or an infrastructure, namely the design stage, the operational stage, or the post-construction stage, as presented in [65].

- Typically, in the design stage, aspects of architectural design, structural analysis, mechanical, electrical, and plumbing (MEP) assessment, as well as other analysis including environmental and energy assessment are implemented.

- The implementation of BIM during the construction stage includes the monitoring of the construction progress, as well as health and safety issues.

- Post-construction BIM is related to the monitoring of the operation of a building, typically in terms of digital twins and the application of IoT and machine learning practices.

- Additionally, BIM is employed for the post-construction assessment of the buildings' operational assessment, including actual energy behavior.

Some of the advantages of using BIM include the better collaboration and communication between the design engineers, the cost estimation of the model, the increased productivity, the enhanced scheduling, the improved coordination and the reduced cost and mitigated risk. BIM represents the epitome of digital design techniques and constitutes one of the major streams of the Industry 4.0 era. The integration of BIM into buildings design-related processes is a practice compatible with the sustainability features of the built environment. [65] Unavoidably, BIM has already been integrated into the Construction Sector of numerous European Member States, as well as into the European Union Acquis, allowing the development of policies on digital transformation of the built environment $[66,67]$. BIM is applied in a wide range of fields of the building sector (Figure 8), including the energy assessment of buildings 25 and the whole life cycle assessment of buildings [68], as well as of specific building elements such as Plumbing and Electromechanical (PEM) applications [69]. 


\section{RESEARCH TRENDS IN BUILDING INFORMATION MODELLING}

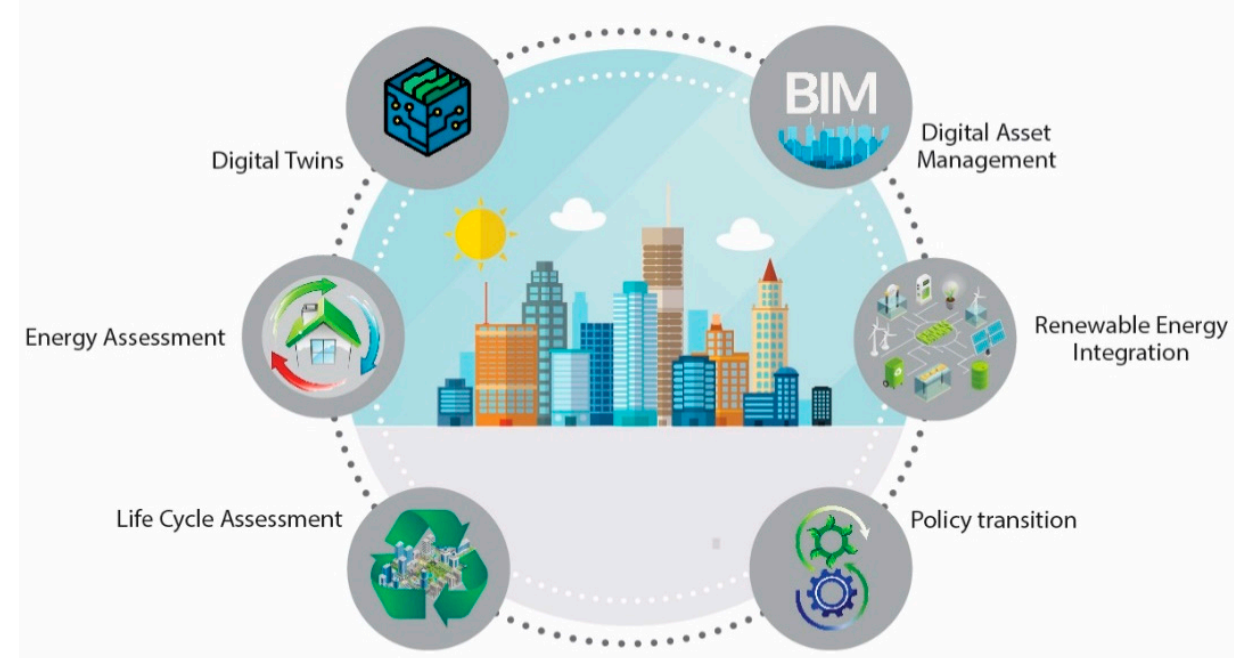

Figure 8. Research Trends in Building Information Modelling [70].

Typical applications of BIM include:

- The design of potential installations of renewable energy technologies in buildings [71]. In this application, an accurate 3D model of a specific area can be reconstructed with the use of photogrammetry, and the energy yield can be calculated with the use of photovoltaics (PV) panels.

- The development of digital models of urban blocks and cities [72]. The digitalization of the built environment allows the implementation of digital twin technologies for the monitoring and management of city assets. The digitalization of the whole life cycle of the built environment enhances the public's quality of life, encourages an innovative culture, delivers more value and increases productivity for cities and infrastructure. Digital city models are intended for objects scanning and the development of digital models with accurate geometry. Possibilities to add attributes, such as energy performance indicators and asset tagging, and to analyze the texture and views with Artificial Intelligence algorithms are also possible. Photogrammetry can be employed to gather digital data about existing buildings and assets.

- The development of tools for increasing the efficiency of the life cycle processes of public sector structures using BIM [73].

- The use of BIM for the dynamic energy assessment of buildings, and specifically for the energy classification of buildings, will enable the issuance and update of new energy performance certificates (EPCs) on a regular basis [74].

\subsection{Environmental Geomatics}

Geomatics is defined as a systemic, multidisciplinary, integrated approach to selecting the instruments and the appropriate techniques for collecting, storing, integrating, modelling, analyzing, retrieving at will, transforming, displaying, and distributing spatially georeferenced data from different sources with well-defined accuracy characteristics and continuity in a digital format. Environmental geomatics compiles numerous concepts and practices, applied to monitor and manage natural resources. The main techniques under environmental geomatics encompass (Figure 9) 


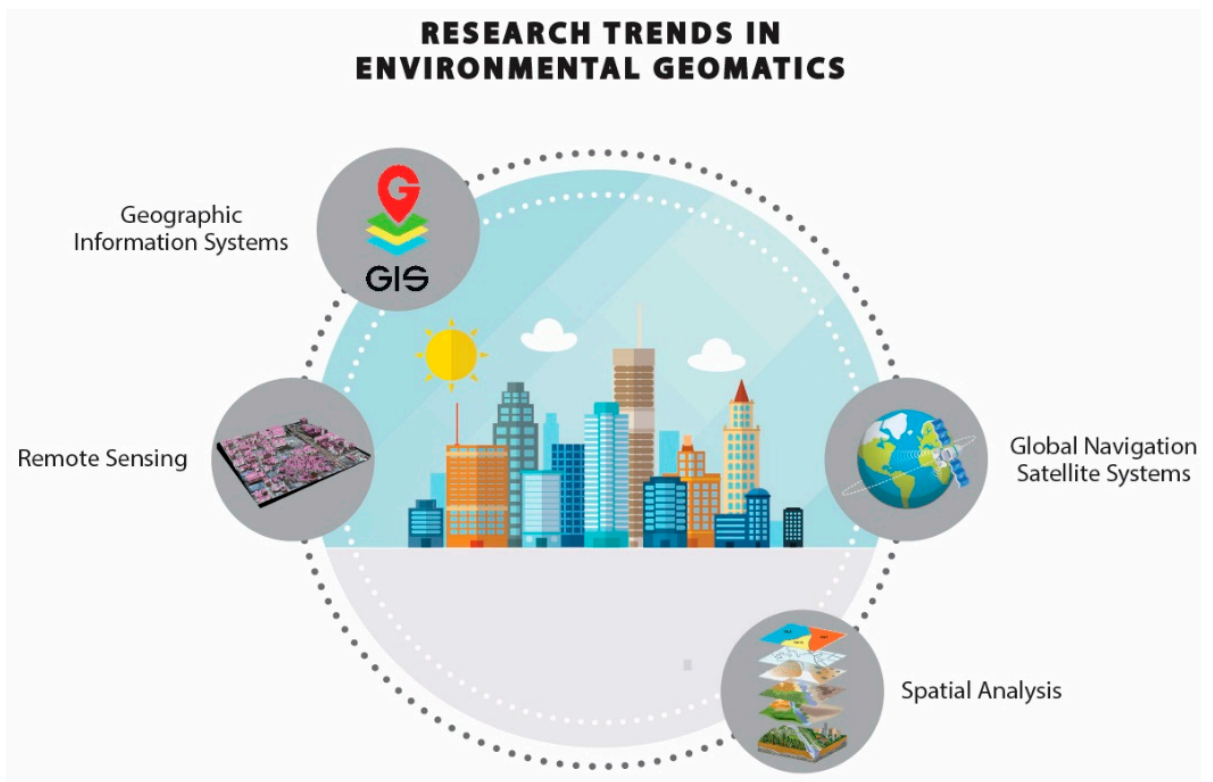

Figure 9. Research Trends in Environmental Geomatics.

- applications in the field of geographic information systems (GIS),

- remote sensing, which uses terrestrial, marine, airborne, and satellite-based sensors to acquire spatial data,

- global positioning systems (GPS) and global navigation satellite system (GNSS), an umbrella term that includes all GPS.

- $\quad$ spatial analysis.

Within the applications in this field, the development of spatial databases from different data sources and the application of this information to solve environmental problems is included.

Typical applications in the field of environmental geomatics include GIS analysis for the quantification of the yield of energy crops, and moreover to define exact sites that would satisfy the necessities of designated energy crops. A comprehensive system for the manufacture of low-density polyethylene (LDPE) film using recycled APW, presenting an enormous opportunity for the plastics manufacturing industry, is presented in [75]. Emphasis is also placed on the development of supply chain models of waste management, based on the classification of geographical clusters, mapped with the use of geographical information system (GIS) [76]. The evaluation of measurement methods of producing topographic maps, including laser scanning and tachometry, as well as the analysis of the accuracy of different geodesic measurements methods, has also been investigated in some studies [77]. Typical applications in this field include, for example, the analysis and assessment of the classical total station method and the mobile laser scanning [78].

\subsection{Environmental Assessment of Building Products and Buildings: Life Cycle Assessment}

Several policy initiatives are currently implemented in the field of sustainable development of the building sector. The European Commission (EC) has set a number of directives and regulations in order to achieve energy efficient products through eco-design and energy labelling. The European Directive 2009/125/EC [79] establishes a framework for the setting of co-design requirements for energy-related products. This directive contributes to the sustainable development by increasing protection of the environment, increasing energy efficiency, and security of the energy supply. The European Union's "Circular Economy Action Plan" [80] promotes initiatives throughout the entire life cycle of product, encouraging sustainable consumption and pointing to initiatives to ensure minimization of the use of resources and making sustainable products the norm in the EU [81]. The United Nations have also announced the Sustainable Development Goals, a collection of 17 global goals designed to be a 
"blueprint to achieve a better and more sustainable future for all". The SDGs were set in 2015 by the United Nations General Assembly and are intended to be achieved by the year 2030 [82].

Life cycle assessment (LCA) is an environmental management technique which allows the evaluation of the environmental impact of building products and buildings throughout their entire life. The LCA boundaries can extend from gate to gate, from cradle to grave. LCA stages include the definition of the goal and scope, the development of the inventory, the definition of the impacts and the interpretation of the results.

LCA can assist in [83]:

- improving the environmental performance of building products, at various stages of their life cycle,

- the decision making in building product design process,

- the selection of relevant indicators of environmental performance,

- marketing.

- LCA is considered as the main tool for achieving sustainable construction practices.

The standards under the ISO 14040 umbrella are devoted to several aspects of the design and implementation of LCA [84]. The scope of the assessment is to result in the optimal construction and management conditions, which will lead to the reduction in natural resources consumption. A sustainable and environmentally friendly approach in the construction sector could be achieved through all stages of building: from extraction of materials for manufacturing the construction products, through the operation of building as well as through the demolishing process and reuse of materials.

LCA got significant attention from the researchers in the last decade. Web of Science search results reveal 18,589 records for the topic of LCA (for the period of 1990-2019) (Figure 10). By analyzing the last decade, 2010-2019, there are 14,183 scientific papers on this topic in Web of Science data base (Figure 11). The top 10 research areas of the analyzed period are presented in Figure 11.

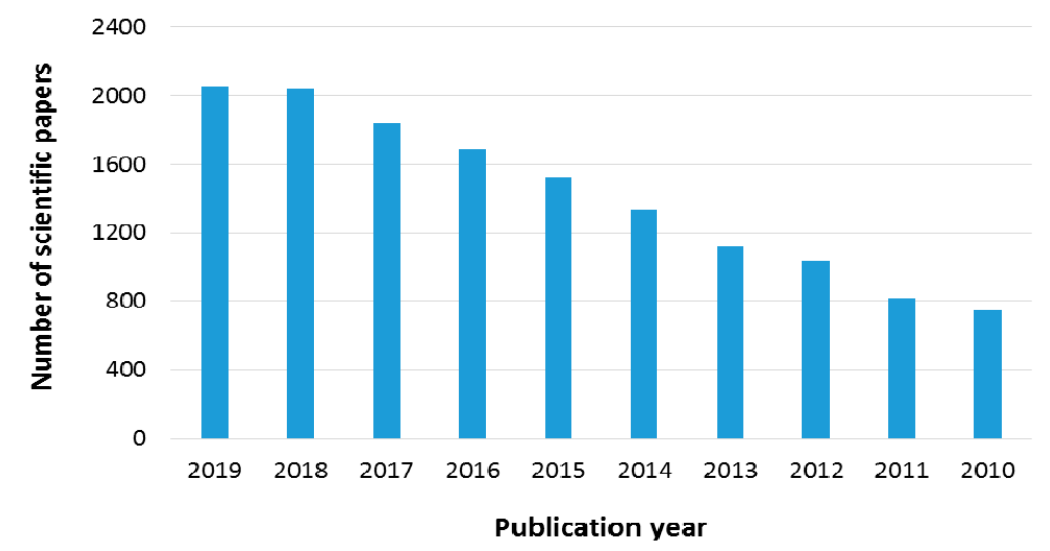

Figure 10. Number of scientific articles for the Life Cycle Assessment (LCA) topic (2010-2019).

LCA application in the building sector could be employed either for building components and materials, or for the entire building (Figure 12). Numerous LCA databases (academic, commercial, or public) which are used in the building sector. Significant databases include BEE, DBRI4 Database, Ecoinvent, ECO-it, ECO methods, Eco-Quantum, Gabi, IO-database, IVAM, KCL-ECO, LCAiT, Simapro, Spin [85]. LCA databases are regional due to the different conditions of energy production per location, hence the different environmental impacts related to energy input. 


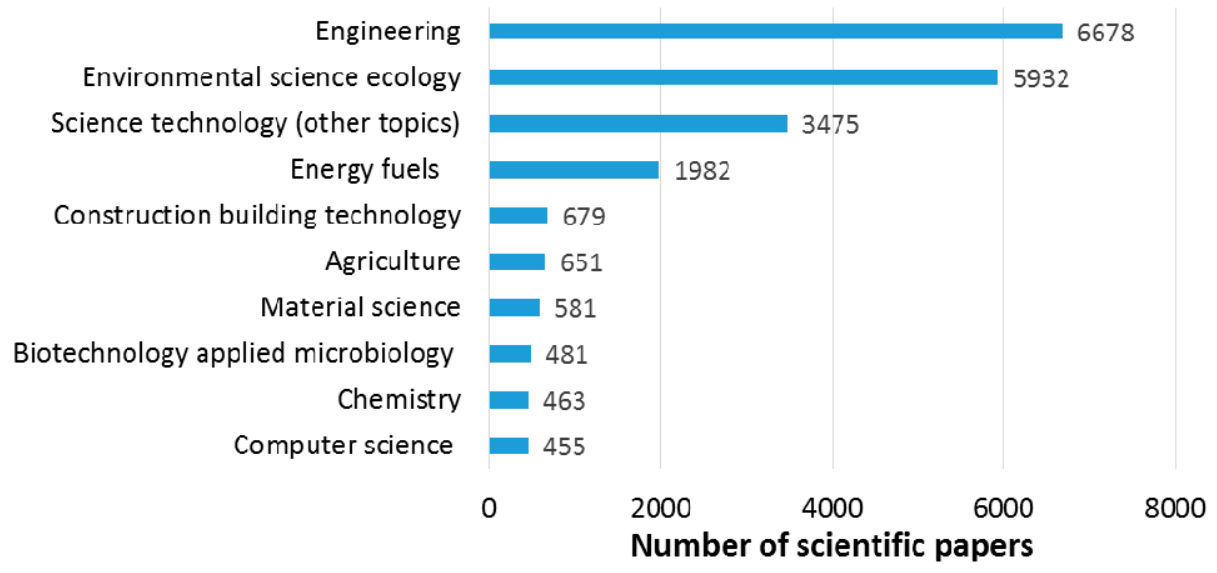

Figure 11. Top 10 research areas for the LCA (2010-2019).

\section{RESEARCH TRENDS IN \\ BUILDINGS LIFE CYCLE ASSESSMENT}

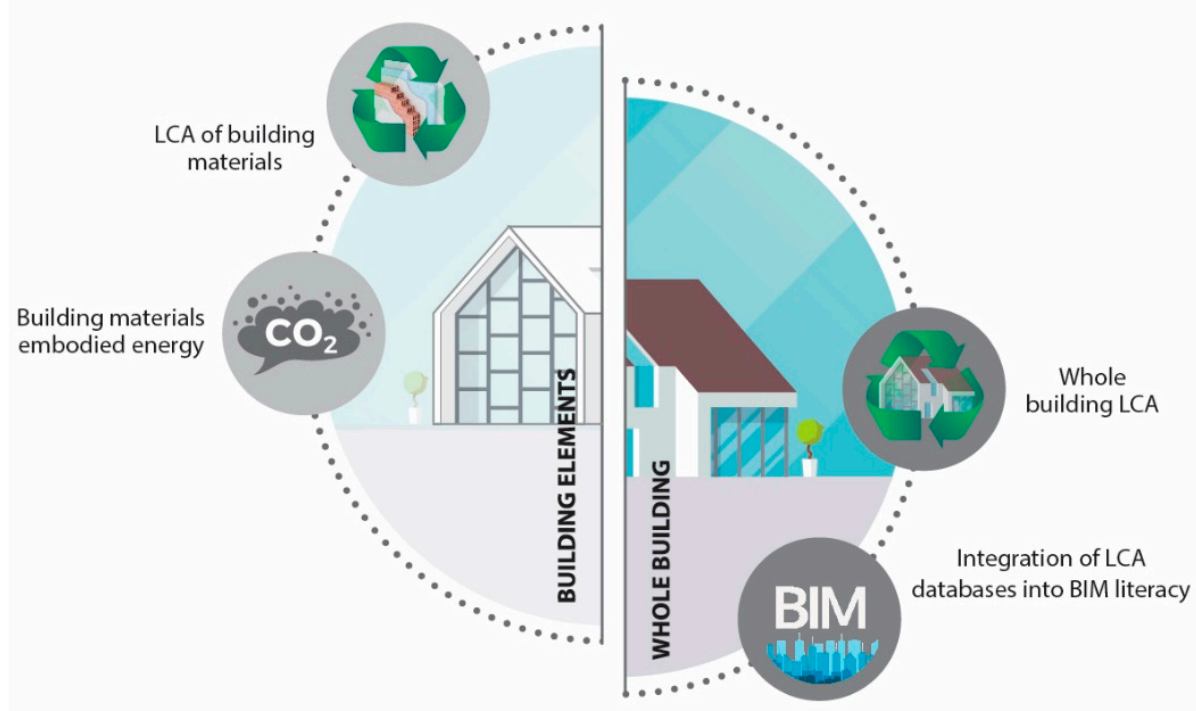

Figure 12. Major trends in the field of Life Cycle Assessment for the built environment.

The LCA studies implemented for the building sector mainly focus in three areas:

- the assessment of individual building materials and building components. These studies mainly analyze alternative production processes and conclude at those production practices which are the least harmful for the environment. On some occasions the energy payback period of building materials is also defined [86-89].

- $\quad$ studies focusing on the entire building. In these studies, comprehensive LCA databases are used, and the studies focus on the performance of the entire building, mainly through matrices in which the building of quantities is combined with the environmental indicators of individual building materials $[90,91]$

- the integration of LCA databases into BIM models for the assessment of the entire building at the design stage $[68,69,92,93]$. This trend is anticipated to prevail in the near future, whereas commercialized tools, such as Tally, have already been launched [94]. 


\section{Future Research Trends in the Scientific Fields of Sustainable Energy in the Built Environment}

This study aimed to give an overview of the main research advancements in the field of sustainable energy in the built environment through a comprehensive compilation of the work of the Sustainable Energy Research Group of the Faculty of Civil Engineering and Architecture at the Kaunas University of Technology. This study adds up to previous overview studies on the use of environmental assessment tools [95] and building and infrastructure sustainability reporting tools [96]. The research fields of the recent years in the field of the sustainable built environment revealed some of the main future research trends focusing on the field of energy. It is certain that research in the following years will aim towards the transition of buildings into smart units, which will enable their smooth integration into smart cities. This transition requires the digitalization of the design, monitoring, and control of data and information related to the energy assessment of the built environment, either through ICTs, BIM, digital twins and smart grids. In view of the fact that Information Communication Technologies (ICTs) are advancing at a fast pace, the digitalization of the building sector will significantly contribute to the objectives of the European Union on the improvement of the sector's energy efficiency and environmental performance. The energy saving opportunities that arise with the development of smart control and regulation systems in buildings are related to the fact that data and information for a variety of factors that directly or indirectly affect the energy consumption of the building (interior human comfort, external climatic environment, requirements for lighting, electricity and hot water) are captured in real-time, and can respond swiftly and appropriately to increase the occupants' comfort and to reduce the building's energy consumption. Furthermore, the adoption of the digital twins concept in the built environment has the potential to further accelerate the benefits from the development of smart sensors systems. Given that digital twins are built on data, the development of a well-designed framework, where the synergies between the different digital technologies are well defined and interoperation is kept at optimum conditions, can significantly contribute to the energy efficiency and smartness of buildings due to enhanced understanding and targeted response to the building's performance data.

Smart grids cost-efficiently integrate the behavior and actions of all their users, namely generators, consumers, and those that are both generators and consumers, in such a way that an economically efficient, sustainable power system with low losses and high levels of quality and security of supply and safety is ensured. Since smart grids employ innovative products and services, intelligent monitoring, control, communication, and self-healing technologies, they are expected to facilitate the connection and operation of generators of all sizes and technologies, increase the consumers' role in the optimization of the operation of the whole system, and provide them with more information on their energy consumption in buildings and reduce the system's environmental impact, as well as increase the system's reliability, quality, and security of supply. Furthermore, since smart grids automatically monitor energy flows and are flexible enough to adjust to changes in energy supply and demand, they have a significant role to play for the integration of the increasing amounts of variable renewable electricity produced by renewable energy sources (RES) as well as the integration of new loads such as EVs charging, without jeopardizing the system's stability or efficiency. To enable this increased demand for communication between smart grids, buildings, renewable energy technologies and building services, the smart cities will also have to significantly advance their $5 \mathrm{G}$ networks.

Author Contributions: Conceptualization, P.A.F..; methodology, P.A.F.; investigation, R.A.; J.Č.; A.J.; E.K.; V.K.-N.; D.P.; D.R.; J.S.; L.S. (Lina Seduikyte); L.S. (Laura Stasiuliene); J.V.; R.V.; T.Ž.; resources, R.A.; J.Č.; A.J.; E.K.; V.K.-N.; D.P.; D.R.; J.S.; L.S. (Lina Seduikyte); L.S. (Laura Stasiuliene); J.V.; R.V.; T.Ž.; writing一original draft preparation, R.A.; J.Č.; A.J.; E.K.; V.K.-N.; D.P.; D.R.; J.S.; L.S. (Lina Seduikyte); L.S. (Laura Stasiuliene); J.V.; R.V.; T.Ž.; writing-review and editing, P.A.F.; visualization, P.A.F.; supervision, P.A.F.; project administration, J.C.; E.K.; D.R.; L.S. (Lina Seduikyte); L.S. (Laura Stasiuliene); J.V.; R.V. All authors have read and agreed to the published version of the manuscript.

Funding: This research received no external funding.

Conflicts of Interest: The authors declare no conflict of interest. 


\section{References}

1. United Nations Development Programme (UNDP) Sustainable Development Goals. Goal 7: Affordable and Clean Energy. 2020. Available online: https:/www.undp.org/content/undp/en/home/sustainabledevelopment-goals/goal-7-affordable-and-clean-energy.html (accessed on 20 July 2020).

2. Kaunelienè, V.; Prasauskas, T.; Krugly, E.; Stasiulaitienè, I.; Čiužas, D.; Šeduikytè, L.; Martuzevičius, D. Indoor air quality in low energy residential buildings in Lithuania. Build. Environ. 2016, 108, 63-72. [CrossRef]

3. Šeduikyte, L.; Bliūdžius, R. Pollutants emission from building materials and their influence on indoor air quality and people performance in offices. J. Civ. Eng. Manag. 2005, 11, 137-144. [CrossRef]

4. Ciuzas, D.; Prasauskas, T.; Krugly, E.; Jurelionis, A.; Seduikyte, L.; Martuzevicius, D. Indoor air quality management by combined ventilation and air cleaning: An experimental study. Aerosol Air Qual. Res. 2016, 16, 2550-2559. [CrossRef]

5. Building Research Establishment What is BREAM? 2020. Available online: http://www.breeam.com (accessed on 20 July 2020).

6. Leadership in Energy and Environmental Design LEED is Green Building. 2020. Available online: http://www.usgbc.org/about (accessed on 20 July 2020).

7. Wei, W.; Ramalho, O.; Mandin, C. Indoor air quality requirements in green building certifications. Build. Environ. 2015, 92, 10-19. [CrossRef]

8. European Committee for Standardization (CEN). EN 13779:2007. Ventilation for Non-Residential Buildings-Performance Requirements for Ventilation and Room-Conditioning Systems; CEN: Brussels, Belgium, 2007.

9. Zhang, Y.; Xiong, J.; Mo, J.; Gong, M.; Cao, J. Understanding and controlling airborne organic compounds in the indoor environment: Mass transfer analysis and applications. Indoor Air 2016, 26, 39-60. [CrossRef]

10. Cheng, Y.H.; Lin, C.C.; Hsu, S.C. Comparison of conventional and green building materials in respect of VOC emissions and ozone impact on secondary carbonyl emissions. Build. Environ. 2015, 87, 274-282. [CrossRef]

11. Schieweck, A.; Bock, M.C. Emissions from low-VOC and zero-VOC paints-Valuable alternatives to conventional formulations also for use in sensitive environments. Build. Environ. 2015, 85, $243-252$. [CrossRef]

12. Stasiuliene, L. Combined Impacts of Indoor Climate Systems in Buildings on Occupant Inhaled Volatile Organic Compounds Concentration. Doctoral Thesis, Kaunas University of Technology, Kaunas, Lithuania, 2016.

13. Jurelionis, A.; Gagyte, L.; Seduikyte, L.; Prasauskas, T.; Ciuzas, D.; Martuzevicius, D. Combined air heating and ventilation increases risk of personal exposure to airborne pollutants released at the floor level. Energy Build. 2016, 116, 263-273. [CrossRef]

14. Jurelionis, A.; Stasiuliene, L.; Prasauskas, T.; Martuzevicius, D. (2018). Dispersion of indoor air pollutants emitted at near-floor levels in rooms with floor heating and mixing ventilation. Indoor Built Environ. 2018, 27, 205-218. [CrossRef]

15. Gagyte, L.; Jurelionis, A.; Martuzevicius, D.; Prasauskas, T. Experimental study of personal exposure to pollutants released at floor level: Floor heating vs air heating. In Proceedings of the 14th International Conference on Indoor Air Quality and Climate, Ghent, Belgium, 3-8 July 2016; pp. 3-8.

16. Stasiuliene, L.; Jurelionis, A. Dispersion of pollutants released at floor level under three types of heating systems: A CFD study. In Proceedings of the HB2017-Europe: Healthy Buildings 2017-Europe, Poland. International Society of Indoor Air Quality and Climate, Lublin, Poland, 2-5 July 2017. P0188.

17. Seduikyte, L.; Stasiulienè, L.; Prasauskas, T.; Martuzevičius, D.; Černeckienè, J.; Ždankus, T.; Fokaides, P. Field measurements and numerical simulation for the definition of the thermal stratification and ventilation performance in a mechanically ventilated sports hall. Energies 2019, 12, 2243. [CrossRef]

18. Jurelionis, A.; Gagytė, L.; Prasauskas, T.; Čiužas, D.; Krugly, E.; Šeduikytè, L.; Martuzevičius, D. The impact of the air distribution method in ventilated rooms on the aerosol particle dispersion and removal: The experimental approach. Energy Build. 2015, 86, 305-313. [CrossRef]

19. Jurelionis, A.; Šeduikytė, L.; Čiužas, D.; Martuzevičius, D.; Gagytė, L.; Prasauskas, T.; Krugly, E. Effect of air distribution methods on solid particle dispersion in rooms with forced ventilation. In Proceedings of the ASHRAE IAQ 2013 Proceedings, Environmental Health in Low-Energy Buildings, Vancouver, BC, Canada, 15-18 October 2013. 
20. Moreno-Rangel, A.; Sharpe, T.; Musau, F.; McGill, G. Field evaluation of a low-cost indoor air quality monitor to quantify exposure to pollutants in residential environments. J. Sens. Sens. Syst. 2018, 7, 373-388. [CrossRef]

21. Fokaides, P.A.; Jurelionis, A.; Gagyte, L.; Kalogirou, S.A. Mock target IR thermography for indoor air temperature measurement. Appl. Energy 2016, 164, 676-685. [CrossRef]

22. Tsagarakis, K.P.; Mavragani, A.; Jurelionis, A.; Prodan, I.; Andrian, T.; Bajare, D.; Stasiuliene, L. Clean vs. green: Redefining renewable energy. Evidence from Latvia, Lithuania, and Romania. Renew. Energy 2018, 121, 412-419. [CrossRef]

23. Černeckienè, J.; Vaičiūnas, J.; Valančius, R.; Jurelionis, A.; Zdankus, T. Recent advancements in the use of on-site biomass systems in the built environment. Curr. Sustain. Renew. Energy Rep. 2018, 5, 156-162. [CrossRef]

24. Arnaoutakis, N.; Milousi, M.; Papaefthimiou, S.; Fokaides, P.A.; Caouris, Y.G.; Souliotis, M. Life cycle assessment as a methodological tool for the optimum design of integrated collector storage solar water heaters. Energy 2019, 182, 1084-1099. [CrossRef]

25. Souliotis, M.; Panaras, G.; Fokaides, P.A.; Papaefthimiou, S.; Kalogirou, S.A. Solar water heating for social housing: Energy analysis and life cycle assessment. Energy Build. 2018, 169, 157-171. [CrossRef]

26. Kylili, A.; Fokaides, P.A.; Ioannides, A.; Kalogirou, S. Environmental assessment of solar thermal systems for the industrial sector. J. Clean. Prod. 2018, 176, 99-109. [CrossRef]

27. Valančius, R.; Jurelionis, A.; Jonynas, R.; Katinas, V.; Perednis, E. Analysis of medium-scale solar thermal systems and their potential in Lithuania. Energies 2015, 8, 5725-5737. [CrossRef]

28. Valancius, R.; Cerneckiene, J.; Singh, R.M. Review of combined solar thermal and heat pump systems installations in Lithuanian hospitals. In Proceedings of the EuroSun 2018 Conference of ISES Europe, Rapperswil, Switzerland, 10-13 September 2018; pp. 10-13.

29. Tsagarakis, K.P.; Efthymiou, L.; Michopoulos, A.; Mavragani, A.; Anđelković, A.S.; Antolini, F.; Burlon, S. A review of the legal framework in shallow geothermal energy in selected European countries: Need for guidelines. Renew. Energy 2020, 147, 2556-2571. [CrossRef]

30. Valancius, R.; Singh, R.M.; Jurelionis, A.; Vaiciunas, J. A review of heat pump systems and applications in cold climates: Evidence from Lithuania. Energies 2019, 12, 4331. [CrossRef]

31. Tamašauskas, R.; Bruzgevičius, P.; Šadauskienè, J.; Nikolic, D. Energy efficiency of wind power plants, case of Lithuania. Bulg. Chem. Commun. 2018, 50, 120-129.

32. Tamašauskas, R.; Šadauskienè, J.; Bruzgevičius, P.; Krawczyk, D.A. An evaluation of primary energy factor values of wind turbines. Multidiscip. Digit. Publ. Inst. Proc. 2019, 16, 9. [CrossRef]

33. Ždankus, T.; Černeckienè, J.; Greičius, L.; Stanevičius, V.; Bunikis, N. Wind energy usage for building heating applying hydraulic system. J. Sustain. Archit. Civil Eng. 2019, 25, 63-70. [CrossRef]

34. Zdankus, T.; Cerneckiene, J.; Jurelionis, A.; Vaiciunas, J. Experimental study of a small scale hydraulic system for mechanical wind energy conversion into heat. Sustainability 2016, 8, 637. [CrossRef]

35. Zdankus, T.; Cerneckiene, J.; Jonynas, R.; Stelmokaitis, G.; Fokaides, P.A. Experimental investigation of a wind to thermal energy hydraulic system. Renew. Energy 2020, 159, 140-150. [CrossRef]

36. Fokaides, P.A.; Polycarpou, K.; Kalogirou, S. The impact of the implementation of the European energy performance of buildings directive on the European building stock: The case of the Cyprus Land Development Corporation. Energy Policy 2017, 111, 1-8. [CrossRef]

37. European Parliament. Directive 2002/91/EC of the European Parliament and of the Council of 16 December 2002 on the Energy Performance of Buildings, 2002.

38. European Parliament. Directive 2010/31/EC of the European Parliament and of the Council of 16 December 2002 on the Energy Performance of Buildings, Amending Directive 2002/91/EC, 2010.

39. European Parliament. Directive 2018/844/EC of the European Parliament and of the Council of 16 December 2002 on the Energy Performance of Buildings, Amending Directives 2002/91/EC and 2010/31/EC, 2018.

40. Lagou, A.; Kylili, A.; Šadauskienè, J.; Fokaides, P.A. Numerical investigation of phase change materials (PCM) optimal melting properties and position in building elements under diverse conditions. Constr. Build. Mater. 2019, 225, 452-464. [CrossRef]

41. Fokaides, P.A.; Kylili, A.; Kyriakides, I. Boundary conditions accuracy effect on the numerical simulations of the thermal performance of building elements. Energies 2018, 11, 1520. [CrossRef] 
42. Zdankus, T.; Gylys, M.; Paukstaitis, L.; Jonynas, R. Experimental investigation of heat transfer from a horizontal flat surface to aqueous foam flow. Int. J. Heat Mass Transf. 2018, 123, 489-499. [CrossRef]

43. Šadauskienè, J.; Ramanauskas, J.; Šeduikytė, L.; Daukšys, M.; Vasylius, A. A simplified methodology for evaluating the impact of point thermal bridges on the high-energy performance of a passive house. Sustainability 2015, 7, 16687-16702. [CrossRef]

44. Cerneckiene, J.; Zdankus, T.; Valancius, R.; Fokaides, P.A. Numerical Investigation of the impact of longitudinal thermal bridging on energy efficient buildings under humid continental climate conditions: The Case of Lithuania. IOP Conf. Ser. Earth Environ. Sci. 2020, 410, 012105. [CrossRef]

45. Šadauskienè, J.; Ramanauskas, J.; Vasylius, A. Impact of point thermal bridges on thermal properties of building envelopes. Therm. Sci. 2019, 24, 2181-2188. [CrossRef]

46. Gorse, C.A.; Johnston, D. "Thermal bridge". In Oxford Dictionary of Construction, Surveying, and Civil Engineering, 3rd ed.; Oxford University Press: Oxford UK, 2012; pp. 440-441.

47. Fokaides, P.A.; Christoforou, E.A.; Kalogirou, S.A. Legislation driven scenarios based on recent construction advancements towards the achievement of nearly zero energy dwellings in the southern European country of Cyprus. Energy 2014, 66, 588-597. [CrossRef]

48. Kavga, A.; Vaiciunas, J.; Fokaides, P.A. Recent advancements in the energy performance of intelligent green houses: A Case Study. IOP Conf. Ser. Earth Environ. Sci. 2020, 410, 012030. [CrossRef]

49. Kylili, A.; Fokaides, P.A. Investigation of building integrated photovoltaics potential in achieving the zero energy building target. Indoor Built Environ. 2014, 23, 92-106. [CrossRef]

50. Kylili, A.; Fokaides, P.A. European smart cities: The role of zero energy buildings. Sustain. Cities Soc. 2015, 15, 86-95. [CrossRef]

51. Lithuanian Department of Statistics. Database of Indicators Vilnius. Available online: https://osp.stat.gov.lt/ statistiniu-rodikliu-analize?indicator=S5R005\#/ (accessed on 1 July 2020).

52. ISO 37120:2018. Sustainable Cities and Communities-Indicators for City Services and Quality of Life; ISO: Geneva, Switzerland, 2018.

53. ISO/TR 37121:2017. Sustainable Development in Communities-Inventory of Existing Guidelines and Approaches on Sustainable Development and Resilience in Cities; Technical Committee: Geneva, Switzerland, 2017.

54. Zavadskas, E.K.; Šaparauskas, J.; Antucheviciene, J. Sustainability in construction engineering. Sustainability 2018, 10, 2236. [CrossRef]

55. Apanavičienè, R.; Maliejus, K.; Fokaides, P. Sustainability assessment of the building construction stage using building sustainability assessment schemes (BSAS). IOP Conf. Ser. Earth Environ. Sci. 2020, 410, 012064. [CrossRef]

56. Kylili, A.; Fokaides, P.A.; Jimenez, P.A.L. Key performance indicators (KPIs) approach in buildings renovation for the sustainability of the built environment: A review. Renew. Sustain. Energy Rev. 2016, 56, 906-915. [CrossRef]

57. Seduikyte, L.; Grazuleviciute-Vileniske, I.; Kvasova, O.; Strasinskaite, E. Knowledge transfer in sustainable management of heritage buildings. Case of Lithuania and Cyprus. Sustain. Cities Soc. 2018, 40, 66-74. [CrossRef]

58. Grazuleviciute-Vileniske, I.; Seduikyte, L.; Teixeira-Gomes, A.; Mendes, A.; Borodinecs, A.; Buzinskaite, D. Aging, living environment, and sustainability: What should be taken into account? Sustainability 2020, 12, 1853. [CrossRef]

59. Klumbyte, E.; Bliudzius, R.; Foikades, P. A SIPOC based model for the sustainable management of facilities in social housing. IOP Conf. Ser. Earth Environ. Sci. 2020, 410, 012081. [CrossRef]

60. Klumbyte, E.; Bliudzius, R.; Fokaides, P. Development and application of municipal residential buildings facilities management model. Sustain. Cities Soc. 2020, 52, 101804. [CrossRef]

61. Fokaides, P.A.; Apanaviciene, R.; Klumbyte, E. 5.12 Energy Management in Smart Cities. Compr. Energy Syst. 2018, 5, 457-473.

62. Apanaviciene, R.; Vanagas, A.; Fokaides, P.A. Smart building integration into a smart city (SBISC): Development of a new evaluation framework. Energies 2020, 13, 2190. [CrossRef]

63. Panteli, C.; Klumbyte, E.; Apanaviciene, R.; Fokaides, P.A. An overview of the existing schemes and research trends in financing the energy upgrade of buildings in Europe. J. Sustain. Archit. Civ. Eng. Vol. 2020, 26, 2. 
64. Kylili, A.; Fokaides, P.A. Competitive auction mechanisms for the promotion renewable energy technologies: The case of the $50 \mathrm{MW}$ photovoltaics projects in Cyprus. Renew. Sustain. Energy Rev. 2015, 42, $226-233$. [CrossRef]

65. Panteli, C.; Kylili, A.; Fokaides, P.A. Building information modelling applications in smart buildings: From design to commissioning and beyond A critical review. J. Clean. Prod. 2020, 265, 121766. [CrossRef]

66. Panteli, C.; Polycarpou, K.; Morsink-Georgalli, F.Z.; Stasiuliene, L.; Pupeikis, D.; Jurelionis, A.; Fokaides, P.A. Overview of BIM integration into the Construction Sector in European Member States and European Union Acquis. IOP Conf. Ser. Earth Environ. Sci. 2020, 410, 012073. [CrossRef]

67. Kylili, A.; Fokaides, P.A. Policy trends for the sustainability assessment of construction materials: A review. Sustain. Cities Soc. 2017, 35, 280-288. [CrossRef]

68. Panteli, C.; Kylili, A.; Stasiuliene, L.; Seduikyte, L.; Fokaides, P.A. A framework for building overhang design using Building Information Modeling and Life Cycle Assessment. J. Build. Eng. 2018, 20, 248-255. [CrossRef]

69. Kylili, A.; Fokaides, P.A.; Vaiciunas, J.; Seduikyte, L. Integration of building information modelling (BIM) and life cycle assessment (LCA) for sustainable constructions. J. Sustain. Archit. Civil Eng. 2015, 13, $28-38$.

70. Center for Smart Cities and Infrastructure. 2020. Available online: https://csci.ktu.edu/ (accessed on 15 July 2020).

71. Center for Smart Cities and Infrastructure. Application of Digital Built Environment Model in Structure's Energy Efficiency Modelling (Energija 3D). 2020. Available online: https://csci.ktu.edu/energy-3d/ (accessed on 15 July 2020).

72. Center for Smart Cities and Infrastructure. Kaunas Digital Twins. 2020. Available online: https://csci.ktu. edu/kaunas-digitaltwin// (accessed on 15 July 2020).

73. Center for Smart Cities and Infrastructure. Development of Tools for Increasing the Efficiency of the Life Cycle Processes of Public Sector Structures Using Information Modeling of a Building (BIM-LT). 2020. Available online: https://csci.ktu.edu/bim-lt/ (accessed on 15 July 2020).

74. European Commission. Next-Generation Dynamic Digital EPCs for Enhanced Quality and User Awareness. 2020. Available online: https://cordis.europa.eu/project/id/892984 (accessed on 15 July 2020).

75. Fokaides, P.A.; Tofas, L.; Polycarpou, P.; Kylili, A. Sustainability aspects of energy crops in arid isolated island states: The case of Cyprus. Land Use Policy 2015, 49, 264-272. [CrossRef]

76. Sustainable Energy Research Group."Design and Manufacturing of a Novel Low Density Polyethylene (LDPE) Film for the Construction Industry, Using Recycled Agricultural Plastic Waste (APW)" (ReCyFilm). 2020. Available online: https://www.serg-web.com/research (accessed on 15 July 2020).

77. Kriauciunaite-Neklejonoviene, V.; Rekus, D.; Aksamitauskas, V.C.; Scepanauskas, A. Comparison of measuring methods used in compiling topographical maps for linear engineering structures. In Environmental Engineering, Proceedings of the ICEE International Conference on Environmental Engineering, Vilnius, Lithuania, 22-24 May 2014; (Vol. 9, p. 1); Vilnius Gediminas Technical University, Department of Construction Economics \& Property: Vilnius, Lithuania, 2014.

78. Aksamitauskas, V.Č.; Kriaučiūnaitè-Neklejonovienè, V.; Rekus, D.; Ruzgienè, B.; Puodžiukas, V.; Stanionis, A. Advantages of laser scanning systems for topographical surveys in roads engineering. Balt. J. Road Bridge Eng. 2016, 11, 153-159. [CrossRef]

79. European Parliament Directive 2009/125/EC of the European Parliament and Council Establishing a Framework for the Setting of Ecodesign Requirements for Energy-Related Products, 2009.

80. European Union Circular Economy Action Plan. For a Cleaner and More Competitive Europe. 2020. Available online: https://ec.europa.eu/environment/circular-economy/pdf/new_circular_economy_action_ plan.pdf (accessed on 8 July 2020).

81. European Parliament COM(2020) 98. Communication from the Commission tot the European Parliament, the Council, the European Economic and Social Committee and the Committee of the Regions. A new Circular Economy Action Plan. For a cleaner and more competitive Europe, 2020.

82. Resolution, A. RES/70/1. Transforming Our World: The 2030 Agenda for Sustainable Development; Seventieth United Nations General Assembly: New York, NY, USA, 2015; p. 35.

83. ISO 14040:2006 Environmental Management_Life Cycle Assessment_Principles and Framework; ISO: Geneva, Switzerland, 2006.

84. Pryshlakivsky, J.; Searcy, C. Fifteen years of ISO 14040: A review. J. Clean. Prod. 2013, 57, 115-123. [CrossRef] 
85. Khasreen, M.M.; Banfill, P.F.; Menzies, G.F. Life-cycle assessment and the environmental impact of buildings: A review. Sustainability 2009, 1, 674-701. [CrossRef]

86. Christoforou, E.; Kylili, A.; Fokaides, P.A.; Ioannou, I. Cradle to site life cycle assessment (LCA) of adobe bricks. J. Clean. Prod. 2016, 112, 443-452. [CrossRef]

87. Kylili, A.; Fokaides, P.A. EcoHestia: A comprehensive building environmental assessment scheme, based on Life Cycle Assessment. Procedia Environ. Sci. 2017, 38, 515-521. [CrossRef]

88. Volf, M.; Lupíšek, A.; Bureš, M.; Nováček, J.; Hejtmánek, P.; Tywoniak, J. Application of building design strategies to create an environmentally friendly building envelope for nearly zero-energy buildings in the central European climate. Energy Build. 2018, 165, 35-46. [CrossRef]

89. Kylili, A.; Seduikyte, L.; Fokaides, P.A. Life cycle analysis of polyurethane foam wastes. In Recycling of Polyurethane Foams; William Andrew Publishing: Norwich, NY, USA, 2018; pp. 97-113.

90. Kylili, A.; Ilic, M.; Fokaides, P.A. Whole-building Life Cycle Assessment (LCA) of a passive house of the sub-tropical climatic zone. Resour. Conserv. Recycl. 2017, 116, 169-177. [CrossRef]

91. Harter, H.; Singh, M.M.; Schneider-Marin, P.; Lang, W.; Geyer, P. Uncertainty analysis of life cycle energy assessment in early stages of design. Energy Build. 2020, 208, 109635. [CrossRef]

92. Cheng, B.; Li, J.; Tam, V.W.; Yang, M.; Chen, D. A BIM-LCA Approach for estimating the greenhouse gas emissions of large-scale public buildings: A case study. Sustainability 2020, 12, 685. [CrossRef]

93. Ajayi, S.O.; Oyedele, L.O.; Ceranic, B.; Gallanagh, M.; Kadiri, K.O. Life cycle environmental performance of material specification: A BIM-enhanced comparative assessment. Int. J. Sustain. Build. Technol. Urban Dev. 2015, 6, 14-24. [CrossRef]

94. Autodesk Tally. 2020. Available online: https:/apps.autodesk.com/RVT/en/Detail/Index?id= 3841858388457011756\&ln=en\&os=Win32_64 (accessed on 8 July 2020).

95. Ding, G.K. Sustainable construction-The role of environmental assessment tools. J. Environ. Manag. 2008, 86, 451-464. [CrossRef] [PubMed]

96. Siew, R.Y.; Balatbat, M.C.; Carmichael, D.G. A review of building/infrastructure sustainability reporting tools (SRTs). Smart Sustain. Built Environ. 2013, 2. [CrossRef] 